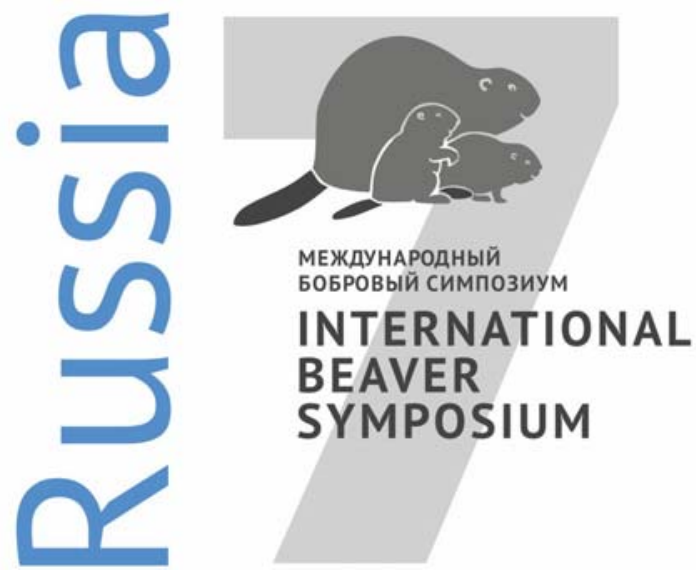

\title{
Note from the Guest Editors of Beaver-Issue of the Russian Journal of Theriology
}

The Seventh International Beaver Symposium was held at the Voronezhsky State Nature Biosphere Reserve near Voronezh, Russia, from September 13-17, 2015. Approximately 100 beaver scientists and interested nonscientists from 18 countries presented new data and joined us for the five-day meeting.

The theme for the 7 IBS was "Beavers - from genetic variation to landscape-level effects in ecosystems".

Altogether 33 talks and 31 posters were presented within five sessions:

1. Biocenotic relation and impact on ecosystems,

2. Genetic and morphology,

3. Behavior and ecology,

4. Status and dynamic of populations,

5. Management and cultural.

Professor Vladimir Georgievich SAFONOV from the Russian Research Institute of Game Management and Fur Farming, Kirov, Russia, was invited as an Honorary President and he attended all symposium sessions and was an active participant. His general knowledge of beaver biology is vast and his numerous journal articles and books about beavers are internationally recognized. Many participants had the pleasure of talking with him during the symposium. Between sessions and in the evenings there was time to discuss future joint projects, visit the world renowned Beaver Nursery and spend time in the modern Beaverium and Museum. The modernized scientific facilities of the Reserve are truly world class and were enjoyed by all the participants.

On the night of the banquet, symposium participants were treated to an outstanding folklore performance that highlighted the cultural diversity of the region. The music, songs and roaring fire all contributed to the magical story that was presented. The banquet that followed was filled with excellent food, a variety of "spirits" and spirited dancing.

The Voronezh weather was its best throughout the symposium, and all who went on the post conference excursion the following day had a fantastic trip under beautiful sunshine. The excursion included a visit to Kostenki on the Don River and its modern paleontology museum. The museum tour was enjoyable as we learned about the prehistoric European settlers and the importance of the Voronezh region as a "pathway" to Europe for Paleolithic humans. The museum was followed by a spectacular lunch in Voronezh and a visit to the shipboard museum commemorating Peter the Great and the establishment of the Russian Navy in Voronezh. The excursion was an excellent way to observe and better understand the "Black Earth" region of Voronezh and its role in the long history of Russia and Europe.

We would like to thank all of you who participated in making the 7th International Beaver Symposium a rewarding intellectual experience and such a scientific success. We also would like to thank the local committee, the Ministry of Natural Recourses and Ecology of Russian Federation, and the sponsors for making this happen.

Abstracts book and general information are available online:

http://therio.ru/news/sbornik-vii-mezhdunarodnogo-simpoziuma-po-bobru/

http://zapovednik-vrn.ru/press-center/announcements/7-mezhdunarodnyj-bobrovyj-simpozium/ 